\title{
Range Lands as Affected by Moringa (Moringa Oleifera) Agroforestry under Semi-Arid Condition of Khartoum State (Omdurman)
}

\author{
Sawsan. F. A. Salih'², I. Bushara', Muna M. M. Ahmed ${ }^{2}$ \\ ${ }^{1}$ Department of Animal Production, Faculty of Natural Resources and Environmental Studies, \\ University of Kordofan El-Obied, Sudan \\ ${ }^{2}$ Institute of Environmental Studies, University of Khartoum.
}

\begin{abstract}
The present study was initiated with the investigate the effect of agroforestry and seasonality (during two successive years) on five range species using moringa tree in the model. The study utilized an enclosure located in a peri-urban area in west Omdurman within Khartoum state. 960 meters square was divided into five blocks were allocated for the plantation with five range species; one used as a control and the other for agroforestry experimentation. Each block was divided into 4 plots and subplots as replicates where range species were randomly selected for plantation trials. Measured parameters included days to germination, flowering and seed setting as well as productivity dry matter yields (ton/hectare). The nutritive value was analyzed for pre-and post-flowering physiological status. Soil samplings were done before and after plantation for the study of soil minerals and $\mathrm{pH}$. The results showed that agroforestry showed significant $(P \leq 0.001)$ positive effects for all range species. During the year 2014, the highest yield was obtained by Dactyloctnium aegyptium (90 Ton), followed by Farsetia longisiliqua Decne (21Ton), then Lasiurus scindicus Henrard (14Ton), Clitoria ternatae (7 Ton) and finally Alysicerpusmonilifer (2.1 Ton). During the year 2015, the highest yield was obtained by Lasiurus scindicus Henrard (2489 Ton)followed by Clitoria ternatae (289 Ton), then Dactyloctnium aegyptium (92Ton)then Alysicerpus monilifer (91Ton) and Farsetia longisiliqua Decne(90 Ton). The effect of year on control and agroforestry treatment, was significant $(P \leq 0.001)$ with better yield for year 2015. Nearly all range species showed the same days for germination ( 8 days), while Moringa showed longer days (21days). For the nutritive value of the plants, crude protein $(C P)$ contents increased in post-compared with pre-flowering. $C P$ increased for Moringa $(P \leq 0.01)$, Dactyloctnium aegyptium and Clitoria ternatae $(P \leq$ 0.05). Dry matter (DM) increased significantly $(P \leq 0.01)$ only in Moringa, whereas, both Dactyloctnium aegyptium and Clitoria ternatae showed significant $(P \leq 0.05)$ decrease in DM. Ether extract content decreased with post-flowering for all plant species, but significant differences were only observed with Moringa $(P \leq$ $0.01)$, Lasiurus scindicus Henrard and Clitoria ternatae $(P \leq 0.05)$. Significant $(P \leq 0.05)$ decreases in ash contents were observed for all plant species with post-flowering except for Moringa which showed significant $(P \leq 0.01)$ increase. Anaylsised soil showed significant improvement after plantation as compared before plantation, however, soil salinity and phosphours was significantly $(P \leq 0.01)$ reduced due to plantation. It could be concluded that the use of agroforestry in range could greatly improve range condition.
\end{abstract}

Keywords: Agroforestry, rangelands, range plant, germination, pre-flowering, post-flowering.

\section{INTRODUCTION}

Sudan is largely an arid to semi- arid country located in East central Africa with an area of 1,881,000 $\mathrm{km}^{2}$. This vast area encompasses different ecological zones extending from desert and semi-desert in the north to low and high rainfall savannah to the south. Nearly $80 \%$ of all rangelands are located in semi-desert and low rainfall savannah ecological zones that are characterized by variable and unpredictable rainfall. Rangelands contribute substantially to income and subsistence of a large sector of the population who are either pastoralists (nomads) or agro-pastoralists by providing important forage feed resource. It supplies about $80 \%$ of the total feed requirement of national herds which are estimated as 105 million heads (MoLFR, 2013). About 14\% of the population is involved in livestock production activities (RPA, 2013). RPA (2009) reported that: almost $86 \%$ of the livestock feed in the country is dependent on the open rangeland, crop residues and other agricultural byproducts which contribute $10 \%$ whereas $4 \%$ of feed come from irrigated forage and concentrates .

The rangelands of importance to traditional livestock raising that are confined to the semi-desert, low rainfall savannah, and the northern fringes of the high rainfall areas. In the semi- desert, the plant 
cover is a mixture of grasses and herbaceous plants intermingled with Acacia trees and shrubs representing the main grazing areas for camel and sheep. Previous records showed that the range carrying capacity is not in balance with livestock feed requirements. There is a gap between current rangeland production and the actual requirement. This gap amounts to 23.35 million tons of TDN (RPA, 2009). Degraded lands can be restored through sustainable land use systems as agroforestry that increase soil organic matter, prevent soil erosion, improve soil structure, increase infiltration rate, decrease rain drop impact, promote salt - leaching, protect the soil from accumulation of toxic substances, and in general enhance the soil conditions and plant productivity. The pastoralists in Khartoum State who are raising cattle, goats and sheep move all the year searching for water and feed for their animals in the rangelands, as their animals suffering from lack of feed $(R P A, 2013)$.

The agroforestry which is an intensive land-use management that optimizes the benefits from biophysical interactions which are created when trees or shrubs are deliberately combined with crops with their impact on reduction of wind erosion, run-off and soil conservation whereas crop rotation promotes soil cover greatly and promotes conservation agriculture (Jama and Zeila, 2005). The trend now is to move from erosion control, to soil quality conservation. The practice of agroforestry can provide poor agropastoralists with the necessary food supply and extra income to improve their quality of life and the health of the surrounding environment. More recently, agroforestry has taken an added importance due to its capacity to increase carbon sequestration in degraded lands and increase the capacity of smallholder farmers to adapt to climate change. The potential of agroforestry to supply animals with high quality feed has been recognized by many authors (Makkar and Becker, 1997; Fuglie, 2001; Mauricio et al., 2008). This research was carried out to study the effect of cultivated of the Moringa tree in rangeland on the range land productivity, to improve range resilience to climate change and provide good forage for livestock in pastoral and agropastoral systems.

\section{MATERIALS AND METHODS}

\section{Area of Study}

This study was conducted in Omdurman area (Umbada locality, longitudes $15.7^{\circ} \mathrm{N}$, Latitudes $34.4^{\circ} \mathrm{E}$ and altitudes $1402 \mathrm{~m}$ above sea levels) Khartoum state.The annual rain fall is $200-400 \mathrm{~mm}$, and the temperature is range $17-20^{\circ} \mathrm{C}$ in the winter and $30-48^{\circ} \mathrm{C}$ in the summer. The pastoralists in the area raise cattle, goats and sheep (7.7 million heads), moving all the year searching for ranges, fodder and water. The areas was occupied by some sedentary tribes with ownership of land and raising small number of animals cattle utilizing the nearby annual low quality pastures and browse trees.

\section{Selected Site}

The selected site is an enclosure of 3 feddans in west Omdurman used as a test of moringa agrofoery model where moringa is planted with vegetables and cereals. 960 square meters was allocated for the research experiment.

\section{Data Collection}

\section{Water Analysis and Irrigation}

Water analysis was done for two sources which were clear well. Parameters studied were sodium and potassium done by Atomic Absorb device. Measurement for $\mathrm{pH}$ was done by $\mathrm{pH}$ meter, ECUS-1 and salinity was measured by Conductivity meter. The plots were irrigated in equal quantity for all the two areas and the trees each 10 days according to need.

\section{Soil}

The soil of the experimental area is generally reddish brown sandy loam to sandy clay loam. They are generally none calcareous, none saline and none sodic soil, with low organic matter and organic nitrogen content. Three Soil samples were collected at $30 \mathrm{~cm}$ in the first year (2014) before plantation and also in the second year (2015) after plantation. Soil samples were analyzed for minerals and organic matter according to the procedure recommended by (Hand book 60, 1954).

\section{Plantation Practices}

Within an enclosure at the study area, 960 square meters was allocated for the experimental research. It was divided into two equal blocks, each block was divided into four plots used for plantation of five range species; one area is used as a control and the other used for agroforestry experimentation. Each block was divided into 5 subplots as replicates where range species were randomly selected for plantation trials. For the agroforestry Moringa trees was planted in as an alley cropping at 3 meter distant apart between trees and the distance between each two blocks was 6 meter. Fives species of 
range were randomly planted in the subplots. These were Dactyloctnium aegyptium, Clitoria ternatae, Lasiurus scindicus Henrard, Farsetia longisiliqua Decneas, Alysicerpus monilifer. Parmaters measured were days to germination, days to flowering and days to seed setting were recorded. In the agroforestry model,

Before sowing, green and dry Moringa oleifera leaves which exist in the area were added to the soil before seed sowing as the soil was poor. Seed sowing for range species were done at $30 \mathrm{~cm}$ depth at a rate of 20 grams for each subplot which was $4 \times 6$ meter (Dagash, 2005). Two seeds of Moringa were placed in each hole. Green manure and dry Moringa oleifera leaves were added to the soil before planting at a rate of 3 grams. The application of urea fertilizer was added after one month of cultivation to the Moringa oleifera trees at the level of 2 gram for each tree. Figure 1 shows plantation of the five range species in a randomized design in 4 replicates subplots.

\section{Productivity}

Dry matter forage productivity in ( $\mathrm{t} / \mathrm{ha}$ ) was obtained for the control area and the agroforestry area, this was done by harvesting the fresh forage from each plot, weighed fresh using a spring balance immediately in the field and left them to be sun dried for two weeks and weighed for dry matter for the two season (2014-2015).Final the fresh and dry yield was calculated in tons per hacter.

\section{Chemical Analysis}

Proximate analysis for Moringa oleifera and the five range plants were evaluated pre and post flowering, for nutritive values according to AOAC (1980). These investigations were done for the $1^{\text {st }}$ and the $2^{\text {nd }}$ season for flowering plants in it.

\section{Statistical Analysis}

Data obtained from the field measurements and chemical analysis was statistically analyzed, using the Statistical Package for the Social Sciences, software package (SPSS, 1999). Analysis of covariance was carried out. Comparison between means was done using unpaired t test to test means significance differences

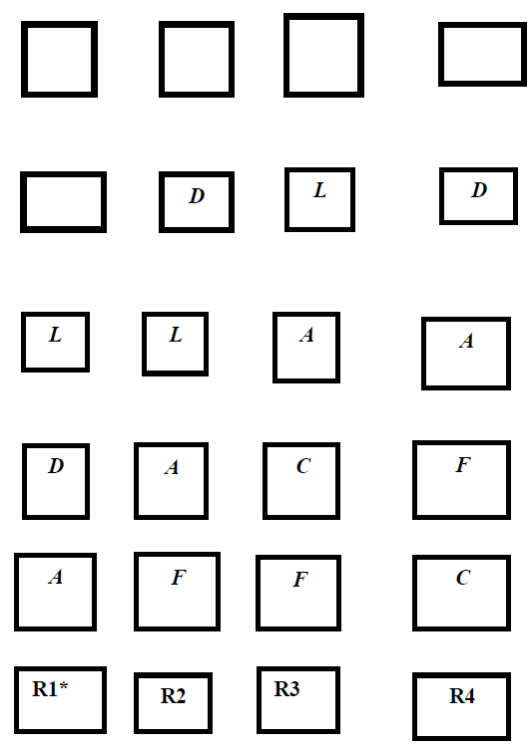

Figure 1. layout of experiment design

$\mathrm{F}=$ Farsetia. $C=$ Clitoria $. L=$ Lasiurus. $D=$ Dactyloctnium. $\mathrm{A}=$ Aysicerpus.

* $(\mathrm{R} 1, \mathrm{R} 2, \mathrm{R} 3, \mathrm{R} 4)$ are the replicates for the range species in the subplots

\section{RESULTS}

Soil Analysis

Soil analysis was done for nitrogen, phosphorus, potassium, salinity and $\mathrm{pH}$ before and after plantation 2014, 2015. Significant differences were obtained for soil phosphorus, salinity and Potassium. Where a decrease was obtained in year 2015 compared with year 2014 (Table 1). 
Table 1. Chemical Soil analysis for the years 2014, 2015.

\begin{tabular}{|l|l|l|l|}
\hline \multirow{2}{*}{ Parameter } & Years & P value \\
\cline { 2 - 4 } & $\mathbf{2 0 1 4}$ & $\mathbf{2 0 1 5}$ & 0.308 \\
\hline Nitrogen \% & $0.0166 \pm 0.005$ & $0.022 \pm 0.001$ & 0.001 \\
\hline Phosphours (mg/I) & $2.100 \pm 0.100$ & $0.20633 \pm 0.020$ & 0.049 \\
\hline Potassium (mmoI+/I) & $0.116 \pm 0.015$ & $0.0813 \pm 0.015$ & 0.011 \\
\hline Salinity (dS/m) & $0.566 \pm 0.057$ & $0.2737 \pm 0.016$ & 0.223 \\
\hline pH & $7.560 \pm 0.07$ & $7.44 \pm 0.11$ & \\
\hline NS = not significant; & \multicolumn{3}{|l|}{} \\
\hline
\end{tabular}

\section{Proximate analysis}

Dry matter, crude protein, ether extract, and ash for pre- and post- flowering different species

The nutritive value for the Moringa under study as dry matter post-flowering was significantly $(\mathrm{P} \leq$ 0.01) higher compared with pre-flowering. Both Dactyloctnium aegyptium and Clitoria ternatae had significantly $(\mathrm{P} \leq 0.05)$ lower dry matter post-flowering compared with pre-flowering (Table 2$)$.

Table 2. Dry matter percent (DM \%) at pre-and post-flowering stage of the plants.

\begin{tabular}{|l|l|l|l|l|}
\hline Plant species & Pre-flowering & Post-flowering & t value & p value \\
\hline Moringa oleifera & $91.08 \pm 0.56$ & $93.98 \pm 0.21$ & -6.275 & $0.008^{* *}$ \\
\hline LasiurusscindicusHenrard & $93.93 \pm 0.17$ & $93.98 \pm 0.21$ & -1.000 & $0.391 \mathrm{NS}$ \\
\hline Dactyloctnium aegyptium & $92.33 \pm 0.33$ & $91.73 \pm 0.59$ & 3.565 & $0.038^{*}$ \\
\hline Farsetia longisiliqua Decne & $93.25 \pm 0.13$ & $93.12 \pm 0.29$ & 0.647 & $0.564 \mathrm{NS}$ \\
\hline Clitoria ternatae & $92.53 \pm 0.39$ & $92.08 \pm 0.42$ & 4.323 & $0.023^{*}$ \\
\hline Alysicerpus monilifer & $93.93 \pm 0.17$ & $93.50 \pm 0.29$ & 0.234 & $0.830 \mathrm{NS}$ \\
\hline NS = not significant; * significant at $\mathrm{P} \leq 0.05=; *$ significant at $\mathrm{P}<0.01$ & \multicolumn{2}{|l|}{} \\
\hline
\end{tabular}

For crude protein all plant species showed increase in crude protein content post-flowering compared to pre-flowering. The increase was significant $(\mathrm{P} \leq 0.01)$ for Moringa, Lasiurus scindicus Henrard, Alysicerpus monilifer as well as for Clitoria ternatae $(\mathrm{P} \leq 0.05)$, but significant $(\mathrm{P} \leq 0.01)$ decrease for Dactyloctnium aegyptium was found (Table 3).

Table 3. Crude protein percent (CP \%) of pre-and post-flowering stage of the plants under study

\begin{tabular}{|l|l|l|l|l|}
\hline Plant species & Pre-flowering & Post-flowering & t value & p value \\
\hline Moringa oleifera & $17.98 \pm 0.05$ & $14.84 \pm 0.18$ & 34.920 & $0.001^{* *}$ \\
\hline LasiurusscindicusHenrard & $3.30 \pm 0.21 \mathrm{~A}$ & $7.61 \pm 0.33$ & -7.227 & $0.005^{* *}$ \\
\hline Dactyloctnium aegyptium & $14.92 \pm 0.25$ & $10.39 \pm 0.51 \mathrm{~B}$ & -39.266 & $0.001^{* *}$ \\
\hline Farsetia longisiliqua Decne & $20.32 \pm 0.16$ & $15.29 \pm 0.47$ & -2.580 & $0.082 \mathrm{NS}$ \\
\hline Clitoria ternatae & $17.18 \pm 0.22$ & $20.10 \pm 0.08$ & 4.839 & $0.017 *$ \\
\hline Alysicerpus monilifer & $17.98 \pm 0.05$ & $18.30 \pm 0.67$ & 34.920 & $0.001 * *$ \\
\hline NS = not significant; $*$ significant at $\mathrm{P} \leq 0.05=; * *$ significant at $\mathrm{P}<0.01$ & \multicolumn{2}{l}{} \\
\hline
\end{tabular}

Ether extract content decreased with post-flowering for all plant species, highly significant differences were observed with Moringa $(\mathrm{P} \leq 0.01)$, Lasiurus scindicus henrard and Clitoria ternatae were showed significant $(\mathrm{P} \leq 0.05)$ (Table 4). Significant $(\mathrm{P} \leq 0.05)$ decreases in ash contents were observed for all plant species with post-flowering. Moringa showed significant increase $(\mathrm{P} \leq 0.01)$ (Table 5).

Table 4. Ether extracts percent (EE \%) of pre-and post-flowering stage of the plants under study

\begin{tabular}{|l|l|l|l|l|}
\hline Plant species & Pre-flowering & Post-flowering & t value & p value \\
\hline Moringa oleifera & $10.08 \pm 0.10$ & $3.23 \pm 0.22$ & 37.749 & $0.001^{* *}$ \\
\hline LasiurusscindicusHenrard & $7.61 \pm 0.33$ & $3.23 \pm 0.22$ & -3.536 & $0.038^{*}$ \\
\hline Dactyloctnium aegyptium & $10.39 \pm 0.51$ & $1.15 \pm 0.24$ & 1.732 & $0.182(\mathrm{NS})$ \\
\hline Farsetia longisiliqua Decne & $15.29 \pm 0.47$ & $1.90 \pm 0.12$ & 1.732 & $0.182(\mathrm{NS})$ \\
\hline Clitoria ternatae & $20.10 \pm 0.08$ & $5.20 \pm 0.08$ & 3.576 & $0.037 *$ \\
\hline Alysicerpus monilifer & $18.30 \pm 0.67$ & $2.80 \pm 0.36$ & 0.742 & $0.512(\mathrm{NS})$ \\
\hline NS = not significant; $*$ significant at P $\leq 0.05=; * *$ significant at P<0.01 & \multicolumn{2}{|l|}{} \\
\hline Table 5. Ash percent $(\%)$ of pre- and post-flowering stage of the plants under study & p value \\
\hline Plant species
\end{tabular}


Range Lands as Affected by Moringa (Moringa Oleifera) Agroforestry Under Semi-Arid Condition of Khartoum State (Omdurman)

\begin{tabular}{|l|l|l|l|l|}
\hline Moringa oleifera & $5.33 \pm 0.24$ & $9.41 \pm 0.41$ & 61.400 & $0.001^{* *}$ \\
\hline LasiurusscindicusHenrard & $10.18 \pm 0.15$ & $9.41 \pm 0.41$ & 3.391 & $0.043^{*}$ \\
\hline Dactyloctnium aegyptium & $15.23 \pm 0.23$ & $14.66 \pm 0.24$ & 4.600 & $0.019^{*}$ \\
\hline Farsetia longisiliqua Decne & $10.18 \pm 0.17$ & $9.76 \pm 0.12$ & 3.247 & $0.048^{*}$ \\
\hline Clitoria ternatae & $9.60 \pm 0.22$ & $8.93 \pm 0.42$ & 4.218 & $0.024^{*}$ \\
\hline Alysicerpus monilifer & $13.08 \pm 0.16$ & $11.95 \pm 0.54$ & 3.422 & $0.042^{*}$ \\
\hline$*=$ significant at $\mathrm{P} \leq 0.05=; * *$ significant at $\mathrm{P}<0.01$ &
\end{tabular}

\section{Plantation Trials}

\section{Days to Germination, Days to Flowering and Days to Seed Setting}

Days to germination, days to flowering and days to seed setting for range plants and Moringa tree under study are shown in (Table 6). Nearly all range species showed the same days for germination ( 8 days), while Moringa showed longer days (21). Lasiurus scindicus Henrard, showed the longest days to flowering (360) and seed setting (400) for it was perennial grass, followed by Clitoria ternatae with 90 and 150 respectively as it was pernnial also. Alysicerpus monilifer and Farsetialongisiliqua Decne showed nearly similar days to flowering. However, days to seed setting were longer (90) for Alysicerpus monilifer than Farsetia longisiliqua (60) as they were seasonally grass. Moringa tree days to flowering and seed setting were 180 and 250 respectively (Table 6).

Table 6. Days to germination, days to flowering and days to seed setting for the range plants and Moringa tree.

\begin{tabular}{|l|l|l|l|}
\hline Plant species & $\begin{array}{l}\text { Days to } \\
\text { germination }\end{array}$ & Days to flowering & Days to seed setting \\
\hline Moringa oleifera & 21 & 180 & 250 \\
\hline Lasiurus scindicus Henrard & 8 & 360 & 400 \\
\hline Dactyloctnium aegyptium & 8 & 30 & 60 \\
\hline Clitoria ternatae & 8 & 90 & 150 \\
\hline Farsetialongisiliqua Decne & 8 & 30 & 60 \\
\hline Alysicerpus monilifer & 10 & 35 & 90 \\
\hline
\end{tabular}

Effect of Year and Agroforestry

Dry Matter Productivity

Table 7. Productivity descriptive statistics. Nova Table

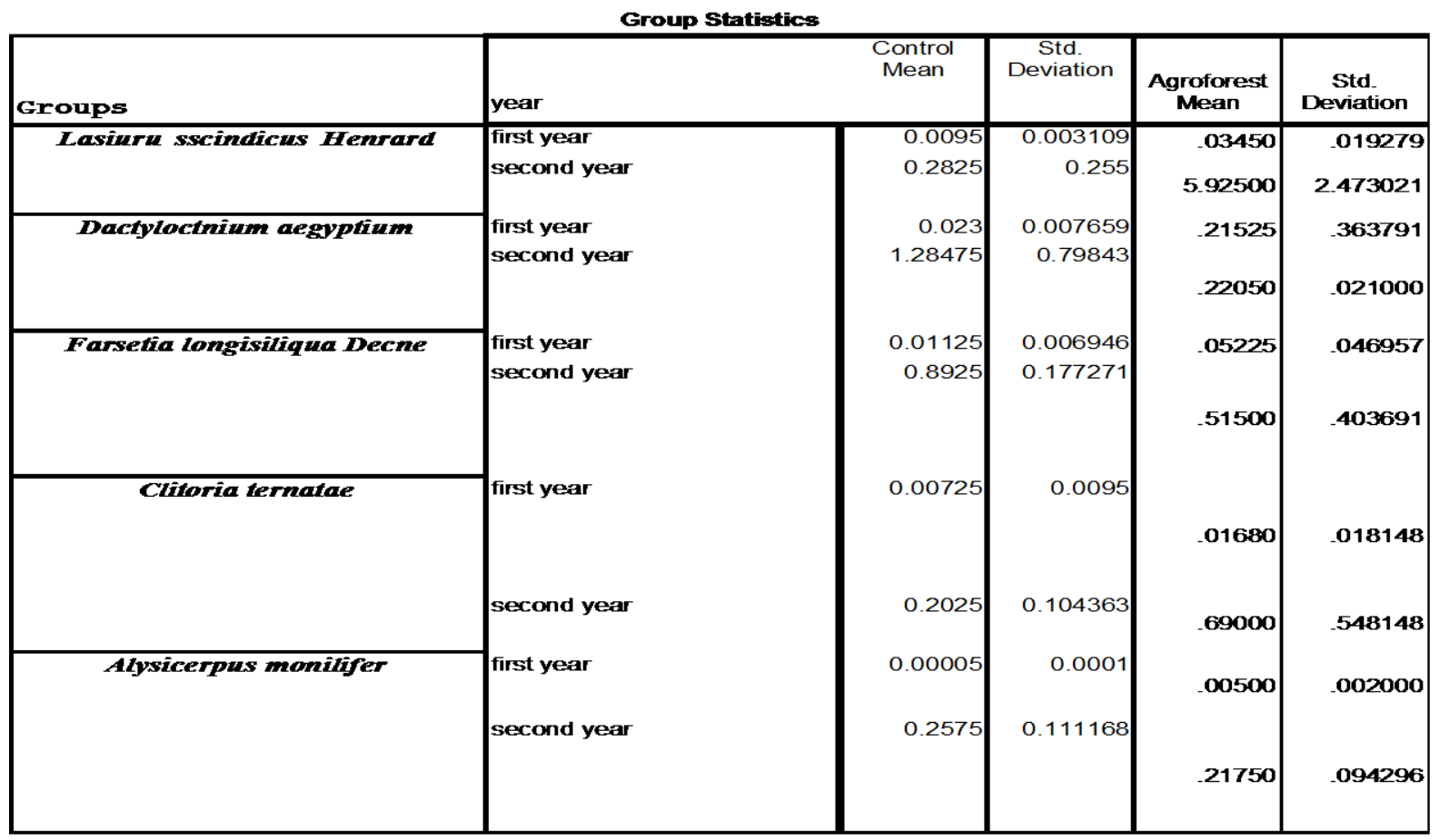


Dry matter productivity (ton/hac) for range species (Table 7) grown under agroforestry conditions with Moringa tree compared to those control were shown for both years 2014 and 2015 there are significant $(\mathrm{P} \leq 0.001)$ increases were obtained for all range species due to the effect of agroforestry during both years. The highest yield was obtained in 2014 by Dactyloctnium aegyptium ( 90 ton/hac), followed by Farsetia longisiliqua Decne (21 ton/hac), then Lasiurus scindicus henrard (14 ton/hac), Clitoria ternatae (7 ton/hac) and finally Alysicerpus monilifer (2.1 ton/hac). During the year 2015, the highest yield was obtained by Lasiurus scindicus henrard (2489 ton/hac) followed by Clitoria ternatae (289 ton/hac), then Dactyloctnium aegyptium (92 ton/hac) then Alysicerpus monilifer (91 ton/hac) and Farsetia longisiliqua Decne (90 ton/hac). For both control and agroforestry treatments, year effect was significant $(\mathrm{P} \leq 0.001)$ where year 2015 gave the highest yields, with Dactyloctnium aegyptium were the least affecting.

\section{DISCUSSION}

\section{A-Soil}

Agroforestry positively affects soil fertility moisture and soil conservation, increase the infiltration capacities, reduce surface runoff and hence reduce erodibility. The study showed that the nitrogen content of the soil was not significantly improved which could be related to the fact that Moringa tree has no root nodules for nitrogen fixation. However, it is a fast growing tree and it has been proposed the practice which involves planting fast growing would produce large quantities of biomass that easily decomposes and release nitrogen for crop growth (Kwesiga et al., 2003). The Potassium was significantly increased whereas the soil salinity was significantly reduced indicated by a reduction in the $\mathrm{pH}$ this could be taken as indication of the positive effect of agroforestry on soil characteristics. Similarly, it was found that stated trees provide all the major nutrients they are capable which is the most limiting major soil nutrient (Ajayi et al., 2006).

They explained that, trees can recycle the soil's phosphorus $(\mathrm{P})$, calcium $(\mathrm{Ca})$, magnesium $(\mathrm{Mg})$ and potassium $(\mathrm{K})$, the tree biomass is then cut and the biomass is incorporated into the soil during land preparation. The better performance of Moringa olifera on sandy loam where it was grown in the study area was in agreement with that of Badaieel (2013) who studied the growth of Moringa olifera on different soil types.

\section{B-Plant Performance}

The nutritive value for the plants under study showed that the crude protein (CP) for the legumes was better than for grasses. Leguminous plant CP is known to be better than grasses. Moringa tree showed higher CP content but less than Clitoria which is considered legume that agreement with Skerman,and Riveros (1990) and Abusuara (2005)who found that the Clitoria productivity was 14 ton and in the farm of agriculture University of Khartoum at a weight of they came at 120 ton. However, with post-flowering, CP of Moringa decreased which could be related to that it could be used for pod and seed formation. As the plants mature organic matter increases while both ether extract and ash were shown to decline. Perennial plants stay on ground for long periods; the annuals usually complete their life cycle within one year with no significant accumulation of dry matter

All range plants under study showed very high productivity in dry matter yields under the agroforestry system during both years, with year 2015 showing the highest productivity. This could be related to the improvement in soil and tree fertilization and better rainfall during the year. This is in line with the findings of Kakengi et al, (1999) who stated that Pastures in eastern Tanzania are subjected to seasonal variations within and between years. They conclude that periods of scanty rainfall have profound effects on quantity and quality of grass pastures available in the communal grazing lands of some parts in Tanzania.

Dry matter yields ranged from 10 - $50 \mathrm{DM} /$ hectare. Similar findings were obtained in Ethiopia where an agroforestry system in an enclosure provided fodder needed for livestock, 8 to 20 ton dry matter/hectare was produced and was also important in conservation of dry land biodiversity (Gebrehiwot, 2004). Also in terms of CP values, the system is impressive, with potential CP values of up to $300 \mathrm{~kg} \mathrm{CP}$ hectare being realized from agroforestry system .The system has the potential too for improving site ecology; trees enrich soil surface through litter fall decomposition and mineralization. Weight loss in animals, especially among young growing animals, was minimized (Kitalyi et al., 2004). Furthermore, for agriculture, farmers benefit from agroforestry as it optimizes biophysical interactions created when trees or shrubs are deliberately combined with crops that have 
its impact on reduction of wind erosion, run-off and soil conservation (Jama and Zeila, 2005).

\section{CONCLUSION}

Degraded lands can be restored through sustainable land use systems as agroforestry that will increase soil organic matter. Generally, enhance the soil conditions and the plant productivity. Agroforestry practice can provide poor agropastoralists with the necessary food supply and extra income to improve their life quality surrounding environment.Agroforestry can contribute to the evolution of sustainable land use in Sudan drylands. This is possible because in the first place agroforestry as a concept was mooted, and devolved, with concerns about ecological and economic sustainability resilience of environment, diversity of income. It is a system that blends production (food and income security at household-and community-level) with ecosystem services.

\section{REFERENCES}

[1] Abusuar, A.O. (2005). Fodder Production in Sudan. University of Khartoum. The Publisher University of Khartoum September 2005.

[2] Ajayi, O.C., Akinnifesi, F.K., Mullila-Mitti, J., DeWolf, J.J. and Atakala,P.W.,(2006). Adoption of agroforestry technologies in Zambia: synthesis of key findings and implications for policy. Paper presented at the Agricultural Consultative Forum (ACF) Policy and Stakeholders' Workshop, 07 December 2006, Lusaka, pp 5-6.Zambia.

[3] AOAC, (1980). Official Methods of Analysis of the Association of official Analytical Chemists. Thirteenth Edition-1980. Agricultural Liming Materials. Fertilizers. Plants. Disinfectants. Hazardous Substances. Benjamin Franklin station, Washington, DC20044.

[4] Badaieel, A. A. ( 2013). Effect of soil type, fertilization and salinity on growth and constituents of Moringa oleifera. Master of Science in agricultural sciences. Faculty of agriculture Cairo University,Egypt.

[5] Fuglie, L.J., 2001. The Miracle Tree: Moringa oleifera: Natural Nutrition for the Tropics, p: 172. The Miracle Tree: The Multiple Attributes of Moringa.

[6] Hand book 60, (1954). Diagnosis and Improvement of Saline and Alkali Soils Agriculture Hand book No. 60. United States Department of Agriculture.

[7] Gebrehiwot, K. (2004). The development of dryland Agroforestry in Ethiopia. Paper presented at the ICRAF Dryland Agroforestry Workshop, 1-3 September 2004. Ethiopia.

[8] Jama, B. and Zeila A. ( 2005). Agroforestry in the drylands of eastern Africa: a call to action. Washington, DC: World Bank.Working Paper Series - World Agroforestry ICRAF Working Paper - no. 1. Nairobi: World Agroforestry Centre p.p2-4.

[9] Kakengi, A.M., Shem, M.N. and Otsyina, P. (1999). Performance of grazing cattle in semi-arid tropics supplemented with Leucaena leucocphala leaf-meal and its cost-benefit analysis. In: proceeding of the $26^{\text {th }}$ Conference of Tanzania Society of Animal Production

[10] Kitalyi A, Nyadzi G and Oduol PA. (2004). The Ngitili System as a platform for agroforestry in the drylands. Annual Review of Agroforestry Science and Innovation Planning Forum: The World Agroforestry Centre (ICRAF) Nairobi, 20-25 ${ }^{\text {th }}$ September 2004. Nairobi: World Agroforestry Centre (ICRAF).

[11] Kwesiga, F., Akinnifesi, F.K., Mafongoya, P.L., McDermott, M.H., Agumya, A. (2003). Agroforestry research and development in southern Africa during the 1990s: review and challenges ahead. Agroforestry systems 59: 173-186.South Africa.

[12] Makkar, H., Becker, K., (1997). Nutrients and antiquality factors in different morphological parts of the Moringa oleifera tree. J. Agric. Sci. 128,311-332.

[13] Mauricio, R., Sousa, L., Moreira, G., Reis, G. and Gonçalves, L., (2008). Silvopastoral systems as a sustainable alternative to animal production in the tropics. In: O. Casteln, A.R. Bernués F.

[14] MoLFR, (2013): Ministry of Livestock Fisheries and Rangelands. Information Centre Annual Report.Sudan 
[15] RPA, (2009). Feed gap report 2009. Range and Pasture General Directorate. Ministry of Animal Wealth, Fisheries and Rangelands Khartoum, Sudan.

[16] RPA (2013). Annual Range Survey Report. Range and Pasture General Directorate, Ministry of Animal Wealth, Fisheries and Rangelands. Khartoum, Sudan.

[17] Skerman, P. J. and Riveros, F. (1990). Tropical Grasses FAO. Plant production and protection series.

[18] SPSS (1999). Statistical package for social sciences, Ver.10.0. Chicago: SPSS Inc. 